\title{
The Psychology of Economic Attitudes - Moral Foundations Predict Economic Attitudes beyond Socio-Demographic Variables
}

\author{
Nikola Erceg \\ University of Zagreb, Faculty of Humanities and Social Sciences, \\ Department of Psychology, Croatia \\ nerceg@ffzg.hr
}

\section{Zvonimir Galić}

University of Zagreb, Faculty of Humanities and Social Sciences, Department of Psychology, Croatia

zgalic@ffzg.hr

\section{Andreja Bubić}

University of Split, Faculty of Humanities and Social Sciences,

Department of Psychology, Croatia

abubic@ffst.hr

\author{
CroEconSur \\ Vol. 20 \\ No. 1 \\ June 2018 \\ pp. $37-70$
}

Received: June 28, 2017

Accepted: April 20, 2018

Research Article

doi:10.15179/ces.20.1.2

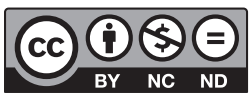

\section{Abstract}

The present study had three goals: to construct a relevant questionnaire of economic attitudes, to examine the role of socio-demographic variables in explaining the economic attitudes as measured by that questionnaire, and to check whether moral foundations, as a psychological construct, can contribute to understanding the economic attitudes beyond socio-demographic variables. The results indicated that the economic attitudes were better explained by two factors instead of one: the Role of the State in the Economy (ROSE) and the Problems with the Current Economic System (PCES). Both socio-demographic variables and moral foundations explained significant amounts of the variance in the results on the two subscales. Regarding the ROSE subscale, socio- 
demographic variables explained 25 percent, while moral foundations explained the additional 21 percent of the variance, resulting in this model explaining 46 percent of the variance in the ROSE results. Regarding the PCES subscale, the socio-demographic variables explained 20 percent of the variance, and moral foundations added another 10 percent resulting in 30 percent of the variance on PCES results being explained by this model. The results speak in favor of including the psychological variables in the studies of economic attitudes and behaviors, and indicate that economic concerns are not only economic in their nature, but also moral.

Keywords: economic attitudes, role of the state, problems with the economy, moral foundations, psychology

\section{JEL classification: A12, A13}

\section{Introduction}

The research into politico-economic literacy of laypeople often shows large gaps in people's knowledge of elementary economic facts. For example, although more than half of the surveyed USA citizens saw economic issues as the biggest problem the nation is facing, two thirds of them did not know that the economy actually grew in the year before the study, 61 percent did not know that defense spending is the largest expenditure area in the federal budget, and 42 percent did not know that the federal budget deficit decreased in the period between 1992 and 2000 (Somin, 2016). Rare studies into economic literacy in Croatia paint a similar picture. For example, the majority of participants showed no familiarity with the economic and financial concepts such as investment fund, internet or phone banking, leasing or securities trading (Vehovec, 2012). Furthermore, more than half of Croatian participants could not correctly calculate the amount of money on a savings account after one year and more than one third did not know that investing their savings in multiple options is safer than putting it all in one place (Vehovec, Rajh, \& Škreblin Kirbiš, 2015). 


\subsection{Characteristics and Outcomes of Laypeople's Economic Attitudes and their Differences from the Attitudes of Economic Experts}

However, although people generally show insufficient economic knowledge, they nevertheless often form and express firm economic ideas and attitudes. Those attitudes are oftentimes in sharp contrast with the attitudes of economic experts. This phenomenon has been discussed before by economists who noticed that, unlike economists, general public often has anti-market attitudes. For example, Schumpeter (1942) thought that people are wary of market and its mechanisms as they relate it to the sense of instability and uncertainty. Hayek (2013) believed that people hold negative attitudes toward market principles primarily because of their negative emotions toward financial institutions and trade. McCloskey (2010) identified three basic beliefs on which the expressed distrust toward capitalism rests: a) the belief that capitalism does not contribute to people's wealth and standard of living; b) the belief that capitalism erodes society's moral foundations; and c) the belief that capitalism creates social and economic inequalities.

Although there are number of speculations about the origins and determinants of laypeople's economic attitudes, the scientific studies in this research area are scarce. Still, economic attitudes can have some important and significant consequences both for the individual and the society. For example, Breeden and Lephardt (2002) concluded that the positive attitudes toward market mechanisms are related to greater achievement and earnings. The other area where economic attitudes can play an important role is the voting behavior. Low economic literacy and attitudes of laypeople that sometimes dramatically differ from those of expert economists can shape election outcomes to the extent that some economic authors even question the functioning of the democratic process (e.g., Caplan, 2011), while others explicitly call for the reduction of the influence of votes on economic policies (see Kirchgässner, 2005). Thus, it seems 
important to study these attitudes in order to gain insight into their structure, determinants, and outcomes.

Existing studies generally point to a high degree of consensus in economic attitudes among economic experts (e.g., Alston, Kearl, \& Vaughan, 1992; Block \& Walker, 1988; Fuller \& Geide-Stevenson, 2007; Kearl, Pope, Whiting, \& Wimmer, 1979). At the same time, general public shows not only a higher degree of disagreement in economic views among themselves (Caplan, 2001), but also disagreement with the views of economic experts in many areas. For example, Haferkamp, Fetchenhauer, Belschak, and Enste (2009) showed that laypeople base their attitudes toward possible reform measures and governmental intervention policies primarily on the criterion of fairness and perceived social justice, while economists almost exclusively focus on the macroeconomic efficiency of those measures. Kirchgässner (2005) believes that, generally speaking, economists are more "right-winged" in their economic views when compared with most of the public, resulting in general public often not sharing their optimism and belief in market functioning.

Many examples from the literature reveal how laypeople's attitudes systematically differ from the attitudes of professionals (i.e., economists). For example, Leet and Lang (2006) showed that social science lecturers supported a bigger role of state in price, wage, and rent controls, as well as various protectionist policies, unlike economic experts who expressed no support for any of the policies. Furthermore, Kahneman, Knetsch, and Thaler (1986) studied the perceptions of the fairness of price formation in various situations. In doing so, they presented participants with a set of situations such as, for example, the following: "A hardware store has been selling snow shovels for $\$ 15$. The morning after a large snowstorm, the store raises the price to $\$ 20$. Please rate this action as: Completely Fair; Acceptable; Unfair; Very Unfair" (Kahneman, Knetsch, \& Thaler, 1986, p. 729). The majority of the participants from a community sample rated this and similar actions as unfair or very unfair. Comparing economics students with non-economics participants, Frey, Pommerehne, and Gygi (1993) showed that 
economics students perceived the price mechanisms as being unfair significantly less often than non-economics participants (84 percent vs. 64 percent). Similarly, Haucap and Just (2010) showed that just 28 percent of non-economics students found this kind of price formation fair, compared to 41 percent of first-year economics students and even 60 percent economists with advanced economic education.

Caplan (2002) claims that the perceived differences in economic views between economists and laypeople cannot be explained by economists' ideological bias, but is mostly a result of various biases in laypeople's perceptions and judgments about the economy. Specifically, following the Kahneman and Tversky's (1982) view that reasoning biases can be diagnosed by comparing individual performances with established facts or some rules of arithmetic, logic or statistics, he identified four biases ordinary people show when reasoning about the economy: a) antimarket bias; b) anti-foreign bias; c) make-work bias; and d) pessimistic bias (Caplan, 2011). The anti-market bias refers to the general inability of laypeople to understand and internalize the concept of the "invisible hand" that is capable of harmonizing private greed and public interest. The anti-foreign bias refers to the underestimation of positive effects of economic interactions with foreigners and is manifested in opposition to foreign trade and immigrants. The make-work bias is manifested in the view that economic prosperity means full employment instead of increased productivity, resulting, for example, in negative attitudes toward downsizing even when it is the result of increased productivity due to technological advancement. Finally, the pessimistic bias refers to the fact that people generally think that the economy is doing worse than it actually is. In conclusion, it seems that economic training and knowledge is one factor that systematically and significantly affects one's economic attitudes. 


\subsection{Determinants and Correlates of Economic Attitudes}

Although many studies focused on the differences between the attitudes of economic experts and laypeople, some went further to look into determinants and correlates of those attitudes, other than economic training and knowledge. Generally speaking, in addition to economic knowledge, factors such as gender, educational level, and socio-economic status were identified as significant correlates of economic attitudes. For example, males' economic attitudes were found to be more congruent with experts' attitudes than those reported by female participants (Caplan, 2001, 2006). These results are in line with Furnham's (1987) conclusion that men show greater support toward free market and entrepreneurship, and lower support for the role of the state in the economy than women. Furthermore, it seems that females have more negative attitudes toward foreign trade than males (Burgoon \& Hiscox, 2004).

Regarding education, studies showed that economic attitudes differed between individuals with different educational levels (Blendon et al., 1997), with more educated individuals being more similar to the majority of expert economists. The effect of socio-economic status on economic attitudes is, on the other hand, less clear. For example, lower socio-economic status, indicated by a participant's family income, was related to quite a few of the constructs measured with The economics values inventory (O'Brien \& Ingels, 1987), one of the most commonly used measures of economic attitudes. One the one hand, lower status seemed to be related to an elevated sense of economic alienation, a lower aversion toward unions, a higher perception of the injustice in the treatment of workers and distribution of income, and more positive views toward the role of the state in the economy. On the other hand, in his studies, Caplan $(2001,2006)$ failed to find a significant effect of the socio-economic status on economic attitudes, albeit using a different instrument for assessing economic attitudes. Thus, the exact role of the socio-economic status in explaining economic attitudes is still unclear and further research in this area is needed. 


\subsection{Our Study}

Despite the long research tradition, as well as the importance of economic attitudes for a range of real-life behaviors and outcomes, the field of economic attitudes attracted little attention in Croatia. To the best of our knowledge, there are currently no studies conducted in Croatia that examine the structure and determinants of economic attitudes. Accordingly, there is no adequate existing measure of economic attitudes that has been used and validated on a Croatian sample. Although several measures of economic attitudes exist, most of them were developed in significantly different historical, cultural, and geographic conditions. For example, The survey on economic attitudes (Soper \& Walstad, 1983 ) and the Economics values inventory (O'Brien \& Ingels, 1987) are often used and properly validated instruments for assessing economic attitudes. However, as both of these measures were developed in the USA in the eighties, it is unclear how those measures would function in Croatia today. Therefore, the first goal of the present study was to create a new tool for the measurement of economic attitudes that will be relevant and appropriate for current domestic context and circumstances.

In order to examine the convergent and discriminant validity of our new measure, we assessed its correlation with self-reported economic and social ideology. Although ideology was long considered to be a unidimensional construct, recently some authors suggested that the two-dimensional view is more appropriate (Duckitt \& Sibley, 2010; Jost, 2006; Jost, Federico, \& Napier, 2009; Jost, Glaser, Kruglanski, \& Sulloway, 2003). In this view, it is possible to distinguish between economic and social conservatism (Duckitt \& Sibley, 2010). The former is related with individual's preference toward inequality, both economic and social, and different ways of dealing with it, while the latter is manifested in the preference for different societal values such as order and tradition versus freedom and expression. Thus, we expected our measure of economic attitudes to be more strongly related with economic than with social ideology. 
Next, we wanted to use our new measure to examine the potential determinants of economic attitudes in Croatia. Therefore, our second goal was to examine the role of socio-demographic variables in explaining the economic attitudes of the general public in Croatia and to compare the results with existing studies mainly conducted in more developed, western economies. As Minarik (2014) noted, due to the specific situation in ex-communist countries, the economic attitudes there have been shaped differently than in liberal countries. That specificity arises from the combination of former communist indoctrination followed by a period characterized by increased economic openness and perhaps more economic insecurity. Namely, all countries in transition go through a period of difficult crisis characterized by a "drastic fall in production, consumption, personal incomes, employment and the living standard as a whole" (Vojnić, 1995, p. 204). Furthermore, this period was, at least in Croatia, characterized by questionable privatization practices that could significantly shape people's views of a capitalist economic system. For example, Sekulić and Šporer (2002) showed that, after the transition period, the members of the ruling party were disproportionately overrepresented among managers, and this perception of unfairness of the outcomes of the privatization process could negatively affect general public's views of the today's economic system. In line with this assumption is Županov's theorizing (2011) corroborated by Burić and Štulhofer's (2016) finding that one of the most prominent values in Croatia today is the "radical egalitarianism", characterized mainly by extremely negative attitudes toward entrepreneurs and a desire for egalitarian redistribution of wages. Thus, it is interesting to see whether this specificity of situation will be reflected in the economic attitudes of Croatians and in the factors influencing economic attitudes in Croatia.

In addition, as our third goal, we aimed to explore the potential determinants of economic attitudes in greater depth by utilizing the concepts from the field of psychology and relating those concepts with economic attitudes. We believe that this approach has a great potential to significantly contribute to the body of knowledge in this field by providing new and more complete answers 
about the structure, formation, and development of economic attitudes. This study is our first step in that direction. In choosing the relevant and potential psychological determinants of economic attitudes, we drew inspiration from related fields, particularly the study of political attitudes. Namely, Furnham (1987) claimed that economic and political beliefs are inextricably linked, and that the determinants and the structure of the former will inevitably point to the determinants and the structure of the latter. Therefore, in defining the potential determinants of economic attitudes, one can draw a parallel with the research on political attitudes.

Among other things, political attitudes proved to be related to moral foundations. Moral foundations are innate and universal psychological systems that represent the "building blocks" of the individual's moral system. Basically, what one thinks is moral or immoral will, at least in part, be based on the moral foundations one relies on when making judgments and decisions in the moral domain. According to Haidt and Joseph (2004), there are five moral foundations upon which one can base his/her moral judgments and decision: harm/care, fairness/ reciprocity, ingroup/loyalty, authority/respect, and purity/sanctity. Thus, due to its extensiveness, the theory of moral foundations emerged as a very useful tool in explaining the diversity of moral worldviews and behaviors, for example sociopolitical ideologies and attitudes.

The first two foundations, harm/care and fairness/reciprocity, emphasize interindividual relations, serve as guiding principles when interacting with other individuals and are, thus, called individualizing foundations. Graham, Haidt, and Nosek (2009) found that liberals, when making moral judgments, are primarily sensitive to possible cruelty, unfairness, and inequality in treating others (i.e. they primarily rely on the individualizing foundations). Unlike individualizing foundations, the latter three foundations are called binding foundations as they serve the purpose of binding individuals into tight communities. For example, people who score high on ingroup/loyalty foundation care deeply about their own social community, those who score high on the authority/respect are sensitive 
to hierarchical relations within their group, and those scoring high on purity/ sanctity foundation emphasize the importance of physical and spiritual purity and control over one's desires. Conservatives are found to rely more on these binding foundations when making moral judgments than liberals, resulting in the fact that they rely similarly on all five foundations, contrary to the liberals who rely primarily on the first two foundations (Graham et al., 2009). Given that moral foundations were significantly related to different political attitudes, there is a possibility that they will also come up as significant predictors of economic attitudes. Therefore, the third goal of this study was to explore the relevance of moral foundations for individual's economic attitudes.

\section{Methodology}

\subsection{Sample}

A sample of 175 subjects participated in this study, 100 of which were males, 74 females and one participant with an unknown gender. The median age of the participants was 28 years $(\mathrm{IQR}=10)$. Regarding educational level, 35 participants had finished high school at most, 40 were attending university at the time of the survey, 79 had finished university studies, 20 had completed postgraduate studies, while one participant left the educational question unanswered. In reference to the employment status, 100 participants were employed, 19 were unemployed, and one participant was retired. The other participants were either students (40) or did not choose any of the previous categories on the employment question.

\subsection{Instruments}

In order to create a new instrument for the study, we first examined the existing measures with the goal of identifying relevant and appropriate items that could be utilized in our instrument. In doing so, we wanted to cover the most salient 
economic issues toward which people usually form and express their attitudes, such as the role of the state in the economy, economic inequality, free market trade, and the role of foreign trade and immigrants. However, it should be noted that our aim here was not to create an exhaustive measure that would cover all the relevant economic aspects and issues since such a venture goes well beyond the scope of this article and our current resources. At this point, we merely tried to cover those economic aspects that are, to the best of our judgment, the most salient in Croatia and that receive most attention from the general public. Next, we translated the items with one author translating them into Croatian, the other back-translating them into English, and the third one doing a comparison and quality assessment of the translation. Finally, we developed some additional items to better account for topics that we thought were underrepresented in the existing item pool. This resulted in a total of 26 items included in the first draft of the questionnaire. All the items included in this draft, together with the study they originate from, can be seen in Table A in the Appendix.

Within the present study and apart from the items measuring economic attitudes and socio-demographic characteristics, the participants also completed the items assessing their self-reported social and economic ideology and the Moral foundations questionnaire (Graham et al., 2009).

Socio-demographic characteristics - participants first reported their age, gender, education, and household income. Regarding the education, they could place themselves in one of six successive categories, starting from "No primary school" to "Completed PhD". Similarly, regarding the household income, the participants placed themselves in one of five successive categories, from "Less than 5,000 kn" to "More than 20,000 kn".

Social and economic ideology - the social and economic ideology was assessed with one item each that asked participants to estimate their ideological stance on economic and social issues on the scale going from 1 - extremely leftist/liberal to 5 - extremely right-winged/conservative. 
The moral foundations questionnaire (Graham et al., 2009) consists of 20 items overall, meaning that each of the five foundations (harm/care, fairness/reciprocity, ingroup/loyalty, authority/respect, and purity/sanctity) is measured using four items. The questionnaire is divided into two parts. In the first part, the subjects evaluate to what extent are certain considerations relevant to their thinking about whether something is right or wrong (e.g., whether or not someone cared for someone weak or vulnerable; whether or not someone violated standards of purity and decency). In the second part, the participants assess their agreement or disagreement with various statements (e.g., justice is the most important requirement for a society; men and women each have different roles to play in society). The final score for the individual foundation is calculated by averaging the responses on the four items measuring that foundation.

\subsection{Procedure}

We constructed an online version of our economic attitudes questionnaire and recruited participants using Facebook groups where they were presented with the questionnaire accompanied by a brief introduction outlining the description of the study, its goals, and the names and contact information of the authors. In order to achieve the diversity of ideological positions of the participants, we chose to post our questionnaire in those Facebook groups where it was possible to guess the ideological position of the majority of its members. Specifically, we focused on support groups for different political parties and socio-political movements of different ideological positions, as we thought this will give us best chances of meeting our goal of ideology diversification. 


\section{Results}

In this section we will describe the main results of our study. We will first describe the process of the development and factorization of our economic attitudes scale. Next, we will present the results of the initial analysis of convergent validity of our new measure. Finally, we will describe the socio-economic and psychological correlates of different dimensions of economic attitudes.

\subsection{Development of the Economic Attitudes Measure}

In order to establish the factorial structure of our questionnaire and to possibly reduce the number of items for the following analysis, we first conducted the factor analysis with oblique rotation (oblimin). Both parallel analysis and Velicer's minimum average partial test (MAP), that proved to be superior to other procedures of factor extraction and typically yield the optimal number of components (O'Connor, 2000), suggested a two-factor solution. In deciding what items to keep for the final version of the questionnaire, we followed two criteria. First, the item had to have minimum factor loading of .40 , which is higher than the minimum of .33 suggested by Tabachnick and Fidell (2013). Second, the criterion of content validity imposed that we sometimes exclude the item even if its loading surpassed .40 . Such was the case if the item was not sufficiently conceptually related to the factor as we described it. These two criteria resulted in the final version of the questionnaire having altogether 13 items. All the items that are included in the final version of the questionnaire are presented in Table 1.

The first extracted factor was best defined by items such as The minimum wage should be increased, and Redistribution of income is in the domain of the government. This factor seems to be determined mostly by the items concerning the governmental influence on wages, income distribution and economy in general, control over the financial sector, tariffs, policies etc. Thus, we decided to 
call it the Role of the State in the Economy (ROSE). The ROSE subscale consisted of eight items overall, with the higher score on this subscale indicating more favorable views toward a greater role of state in the economic activity.

Table 1: The Items Included in the Final Version of the Questionnaire and the Subscales they Constitute

\begin{tabular}{|c|c|}
\hline Subscale & Item \\
\hline \multirow{8}{*}{ ROSE } & 1. Tariffs and import quotas usually reduce general economic welfare. \\
\hline & 2. The distribution of income in your country should be more equal. \\
\hline & $\begin{array}{l}\text { 3. The redistribution of income within the country is a legitimate role for the } \\
\text { government. }\end{array}$ \\
\hline & 4. The level of the legislated minimum wage should be increased. \\
\hline & 5. The extent of government support for agriculture should be increased. \\
\hline & 6. The state must increase its control over the financial sector. \\
\hline & 7. The crisis of the Swiss franc is entirely caused by the banks. \\
\hline & 8. Improving the economy is something an effective government can do a lot about. \\
\hline \multirow{5}{*}{ PCES } & 9. Free trade leads to unemployment. \\
\hline & $\begin{array}{l}\text { 10. One of the major reasons the economy is not doing as good as it could is because } \\
\text { the business profits are too high. }\end{array}$ \\
\hline & $\begin{array}{l}\text { 11. One of the major reasons the economy is not doing as good as it could is because } \\
\text { the top executives are paid too much. }\end{array}$ \\
\hline & $\begin{array}{l}\text { 12. Looking ahead } 20 \text { years, changes that the new technology and competition from } \\
\text { foreign countries are bringing will be bad for the country. }\end{array}$ \\
\hline & $\begin{array}{l}\text { 13. The economy operates in a way that if someone has more, someone else necessarily } \\
\text { must have less. }\end{array}$ \\
\hline
\end{tabular}

Source: Authors' construction.

The second extracted factor was best described by items such as One of the main reasons the economy is not doing as good as it could is because the top executives are paid too much and One of the main reasons the economy is not doing as good as it could is because the business profits are too high. This factor had five items overall, all of which were broadly related to various problems of the today's economic system and current or future factors influencing its proper functioning. Thus, we called this factor Problems with the Current Economic System (PCES). The higher score on this subscale seems to indicate a more unfavorable view of the way the economy is functioning today and of today's economic system in general. 
The two factors were highly correlated $(r=.74, p<.001)$. Thus, in order to verify the appropriateness of the two-factor solution, we conducted the confirmatory factor analysis to assess the goodness of fit of one- and two-factor solutions. The two-factor solution $\left(\chi^{2} / d f=1.91, C F I=0.96, R M S E A=0.072,95 \%\right.$ CI [0.052, 0.091]) was a significantly better fit for the data than the one-factor solution $\left(\chi^{2} / d f=2.95, C F I=0.90, R M S E A=0.106,95 \%\right.$ CI $[0.088,0.123] ; \Delta \chi^{2}(1)=$ $69.48, p<.001)$. Therefore, we decided to treat the two factors separately in the subsequent analysis. Together, these two factors explained 53.86 percent of the variance in subjects' responses. Descriptive statistics and reliability coefficients of the measures used in the study are presented in Table 2.

\subsection{Convergent Validity of the Economic Attitudes Scale}

Next, in order to check for their convergent and discriminant validity, we conducted the correlational analysis to see how the scores on the two dimensions of economic attitudes are related with self-reported social and economic ideology. We expected that the correlation between the economic ideology and economic attitudes will be higher than the one between social ideology and economic attitudes. Confirming our predictions, the correlations between both dimensions of the economic attitudes and self-reported economic ideology were significant, negative, and high. Basically, those who were more right-wing on economic issues were less supportive toward the role of the state in the economy and they also perceived problems with the current economic system to be less serious than those who were more leftist on economic issues. On the other hand, the correlations between economic attitudes and self-reported social ideology were non-significant. All the correlations are presented in Table 2. 


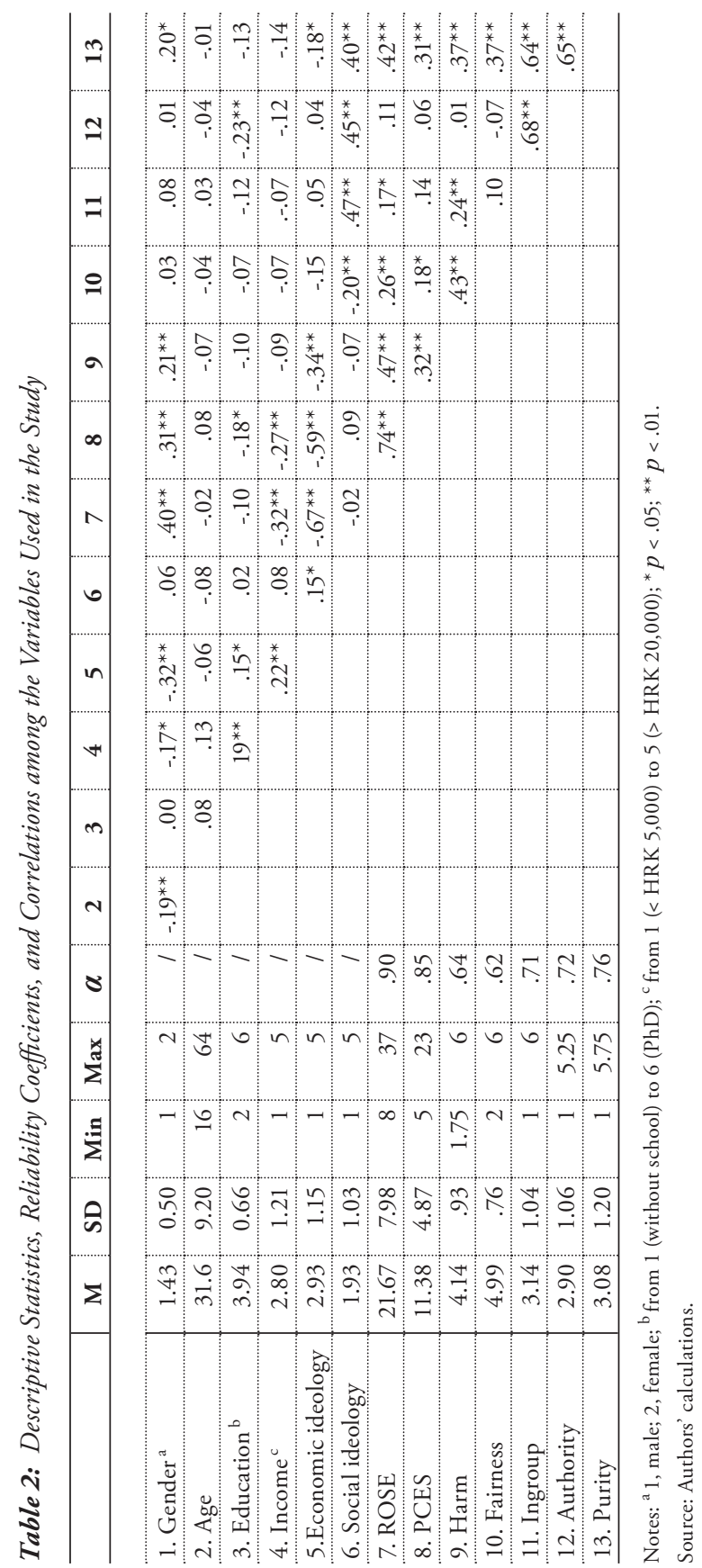




\subsection{Correlates of Economic Attitudes}

In the next step of the analysis, we calculated the correlations among the scores on the two economic attitudes subscales, the socio-demographic characteristics and the scores on the five moral foundations subscales. As can be seen from Table 2, gender is positively correlated with scores on both the ROSE and the PCES which, in this case, means that females prefer a greater role of state in economic activities and hold less favorable views of the current economic system than males. Also, people who live in richer households, in comparison with those from poorer households, show less favorable views toward the role of the state but more favorable views of the current economic system. Education, on the other hand, is significantly correlated only with PCES, but not with ROSE. Namely, more educated participants generally hold more favorable views of the current economic system than the less educated ones, although this correlation is low.

As for the moral foundations, scores on both of the subscales of economic attitudes show similar pattern of relationships with moral foundations. The scores on both the ROSE subscale and the PCES subscale were significantly and positively correlated with the scores on the harm/care, fairness/reciprocity, and purity/sanctity foundations, with the score on the ROSE subscale showing additional positive and significant, albeit low, correlation with the ingroup/ loyalty foundation.

As the scores on the moral foundations subscales showed modest to high inter-correlations, a hierarchical two-step regression analysis was conducted in order to assess the unique contribution of moral foundations, as well as sociodemographic variables, in explaining the economic attitudes. In the first step of the analysis, we included the socio-demographic variables, i.e. age, gender, level of education, and household income. The moral foundations were included in the second step of the analysis. As factor analysis pointed to two different factors of economic attitudes, we conducted two regression analyses using scores on the ROSE subscale and the PCES subscale separately as criterion variables. 
Regarding the ROSE subscale, both socio-demographic variables and moral foundations explained significant amounts of variance in the results on this subscale. Namely, socio-demographic variables explained 25 percent of the variance, while moral foundations explained additional 21 percent of the variance, resulting in this model explaining 46 percent of the variance in the results on the ROSE subscale. Amongst the socio-demographic variables, gender and household income were significant predictors of the attitudes toward the role of the state. Specifically, females favored the state interfering in the economic activities more than males, while higher household incomes predicted more negative attitudes toward the role of state in the economy. Importantly, moral foundations were shown to be important predictors beyond the socio-demographic predictors. Specifically, moral foundations of harm/care and purity/sanctity significantly explained the score on the ROSE subscale. Higher scores on both harm/care and purity/sanctity foundations were predictive of more favorable attitudes toward the role of the state. Moreover, looking at individual predictors, harm/care and purity/sanctity seem to be even stronger predictors of the attitudes toward the role of the state than any of the socio-demographic predictors taken alone. Generally, both socio-demographic variables and moral foundations explained significant portions of the variance in the attitudes toward the role of the state, and, according to Cohen (1988), both of these effects can be classified as large. The results of the hierarchical regression analysis are presented in Table 3.

Somewhat different results were obtained regarding the second PCES subscale. While both sets of variables again explained significant parts of the variance in the results of this subscale, generally, the amount of explained variance was smaller than for the first subscale. This time socio-demographic variables explained 20 percent of the variance and moral foundations explained the additional 10 percent of the variance. Thus, this model explained overall 30 percent of the variance in the PCES results. Although the effects of the socio-demographic variables and moral foundations are somewhat smaller in this case, the obtained effects can still be classified as medium or large according to Cohen (1988). 
Table 3: Two-Step Hierarchical Analysis with Socio-Demographic Variables and Moral Foundations as Predictors and Economic Attitude Subscale Scores as Criteria

\begin{tabular}{|c|c|c|c|}
\hline \multirow{2}{*}{ Step } & \multirow{2}{*}{ Predictors } & \multicolumn{2}{|c|}{ Outcomes } \\
\hline & & ROSE subscale & PCES subscale \\
\hline \multirow{7}{*}{1.} & Gender & $.37^{* *}$ & $.30^{* *}$ \\
\hline & Age & .07 & $.17^{*}$ \\
\hline & Education & -.11 & $-.19^{* *}$ \\
\hline & Household income & $-.26^{* *}$ & $-.22^{* *}$ \\
\hline & $\mathrm{R}$ & .50 & .45 \\
\hline & $\mathrm{R}^{2}$ & .25 & .20 \\
\hline & $F(d f)$ & $13.66^{* *}(4,163)$ & $10.36^{* *}(4,163)$ \\
\hline \multirow{13}{*}{2.} & Gender & $.26^{* *}$ & $.22^{* *}$ \\
\hline & Age & .07 & $.16^{*}$ \\
\hline & Education & -.06 & $-.17^{*}$ \\
\hline & Household income & $-.23^{* *}$ & $-.20^{* *}$ \\
\hline & Harm/care & $.28^{* *}$ & .13 \\
\hline & Fairness/reciprocity & .09 & .06 \\
\hline & Ingroup/loyalty & -.11 & -.01 \\
\hline & Authority/respect & -.06 & -.18 \\
\hline & Purity/sanctity & $.33^{* *}$ & $.29^{* *}$ \\
\hline & $\mathrm{R}$ & .68 & .55 \\
\hline & $\mathrm{R}^{2}$ & .46 & .30 \\
\hline & $\Delta \mathrm{R}^{2}$ & $.21^{* *}$ & $.10^{* *}$ \\
\hline & $F(d f)$ & $15.16^{* *}(9,158)$ & $7.57^{* *}(9,158)$ \\
\hline
\end{tabular}

Notes: ${ }^{*} p<.05 ;{ }^{* *} p<.01$.

Source: Authors' calculations.

Besides the gender and household income that again emerged as significant predictors, the score on this subscale was also significantly predicted by other two socio-demographic variables-age and level of education. Females, as well as older participants, were, overall, more skeptical toward economic functioning today and more prone to finding different disadvantages of the economic system today. At the same time, higher household income and higher education were predictive of lower scores on this subscale. Thus, it seems that the more educated one is and the higher income one has, the more he/she agrees with the current economic functioning and less likely he/she is to find the drawbacks to the 
current system. As for the moral foundations, only purity/sanctity was shown to be a significant predictor of the score on this subscale, with higher score on purity/sanctity predicting higher score on the PCES subscale. The results of the regression analysis are presented in Table 3.

\section{Discussion}

In this study we have shown the complex and multi-dimensional structure of economic attitudes that is further corroborated by findings of different patterns of predictability for different dimensions of economic attitudes. First of all, we constructed two internally consistent scales measuring two aspects of economic attitudes, and conducted the preliminary analysis confirming their convergent and discriminant validity. Next, confirming previous findings about the relevance of socio-demographic variables for economic attitudes, both the ROSE and the PCES dimensions of economic attitudes were significantly predicted by gender and household income, while the PCES dimension was also predicted by age and level of education. Furthermore, this study broadened the body of knowledge in the field of economic attitudes foremost by utilizing insights from the field of psychology and identifying additional important predictors that have previously not been related to economic attitudes. Namely, the moral foundations of harm/ care and especially purity/sanctity have been revealed as important predictors of economic attitudes explaining a significant part of their variances beyond the socio-demographic variables.

In the present study, gender and household income were identified as significant predictors of scores on both of the subscales of economic attitudes. More specifically, women showed more favorable attitudes toward state intervention in economic events and were also more inclined, when compared to males, to find drawbacks to the ways the economy is functioning today. These results seem to be in line with some previous findings revealing differences in economic attitudes between men and women that have indicated that men are generally more 
pro-market and pro-business oriented than women, but also less inclined to support the involvement of state in the economy (Caplan, 2001, 2006; Furnham, 1987). On the other hand, females were shown to be more supportive of social equality and to be significantly lower on social dominance orientation that is linked with support for social welfare programs and extending rights to disenfranchised groups (Pratto, Stallworth, \& Sidanius, 1997; Sidanius \& Ekehammar, 1980). There are two broad theories that could explain the gender differences in the preference toward inequality and dominance. The first one emphasizes different gender social roles, while the other emphasizes different evolved mechanisms of men and women (Eagly \& Wood, 1999). For example, it is possible that the women's socialization for care-taking roles, expressed in mainly female professions such as nursing or teaching, instills a generalized concern for other people that is in line with efforts to reduce inequality and in opposition to social dominance (Pratto et al., 1997). At the same time, it is possible that the different evolutionary pressures acted on males and females, resulting in men developing preference for more violence and competition and women developing proclivity to nurture and care-taking. Whatever the true cause of these gender differences is, it seems that “women's accommodation to the domestic role and to female-dominated occupations favors a pattern of interpersonally facilitative and friendly behaviors that can be termed communal" (Eagly \& Wood, 1999, p. 413).

Furthermore, in the present study, those with higher incomes generally showed more negative attitudes toward the role of the state in the economy, but more positive ones toward the current economic system. These findings were also expected given some previous findings. For example, O’Brien and Ingels (1987) found that a lower socio-economic status was related to more positive attitudes toward the role of state and increased perception of injustice related to the distribution of income and wealth. Although many researchers argue against the importance of variables that reflect one's selfish interest, at least in the public domain such as political beliefs (e.g., Caplan, 2002), our results paint a 
somewhat different picture. The importance of income, which is an example of a "self-interest" variable, for economic attitudes, indicates that people might, in this case, behave in line with their "selfish" interest, i.e. rationally. Thus, it is of no surprise that more well-off people have more favorable views of the current economic system and do not want the government to interfere with it. At the same time, those who do not manage so good within the current system find it necessary to interfere with it and change it. However, it must be noted that there are studies that found no relationship between income and economic attitudes (e.g., Caplan, 2001), thus, it remains to be seen whether these results will replicate in the future.

Unlike gender and income that explained both dimensions of economic attitudes, age and educational level were predictive only of the PCES subscale. Younger and more educated participants seem to find too big profits and wages, as well as income inequalities and foreign competition, far less problematic for the economy than the older and less educated participants. At the same time, age and education were not predictive of the attitudes about the role of state in the economy. The fact that age and educational level predict one, but not the other dimension of economic attitudes, implies that the construct of economic attitudes is multidimensional and complex, and that it may consist of multiple dimensions that are differently related to different variables. It also speaks in favor of the view that, in order to thoroughly assess the determinants and correlates of economic attitudes, one first needs to construct an appropriate measure of economic attitudes that would incorporate all relevant dimensions of economic attitudes. The research on the exact structure and the number of relevant dimensions of economic attitudes, as well as the development of an adequate measure of those dimensions, remains to be pursued in future studies. Generally speaking, the obtained pattern of predictability of socio-demographic variables for economic attitudes on the Croatian sample was expected and quite similar to those obtained in previous studies. 
In addition to replicating the findings about the relationship between economic attitudes and socio-demographic variables, our study showed that moral foundations are also important for the understanding of economic attitudes. Even when controlled for the differences in socio-demographic variables, moral foundations of harm/care and purity/sanctity were predictive of the attitudes toward the role of state, while only purity/sanctity was predictive of the individuals' score on the PCES subscale. Participants who base their moral judgments of actions on considerations of whether any harm to other people was inflicted by those actions were more often in favor of the bigger role of state in the economy. Since the subscale measuring the role of state is mainly composed of items related to government redistributive efforts, this finding makes sense in the way that it is logical to expect that someone who cares deeply about the well-being of other individuals will be supportive of the economic policies intended to better the economic and living conditions of people in need. It also concurs with the findings that harm/care, along with fairness/reciprocity, is the moral foundation dimension particularly endorsed by liberals (Graham et al., 2009) who also support the redistributive role of the state. Furthermore, this direction of the relationship between the score on the harm/care foundation and the ROSE subscale was also predicted from research on social dominance orientation (SDO). SDO is conceptualized as the general attitudinal orientation toward intergroup relations that reflects one's general preference for such relations to be equal versus hierarchical (Pratto, Sidanius, Stallworth, \& Malle, 1994). Since individuals who express lower concern for issues of harm/care generally score higher on SDO (Federico, Weber, Ergun, \& Hunt, 2013; Kugler, Jost, \& Noorbaloochi, 2014), and those who score higher on SDO are generally more conservative and show less support for welfare programs (Pratto et al., 1994), the positive relation between harm/care concerns and more positive views about the role of state in the economy was also expected from this line of research.

The fact that purity/sanctity predicted both of the attitude dimensions is somewhat surprising. Purity/sanctity moral foundation, although not having 
any obvious connection with the economic position one holds, was identified as the single most important predictor of both economic attitude dimensions, with those who score high on purity/sanctity moral concerns scoring higher both on the ROSE subscale and the PCES subscale. However, one would expect a completely opposite pattern of relations between purity/sanctity and these two attitude dimensions. Namely, as this moral foundation is one of the "binding foundations" that are especially endorsed by political conservatives, one could expect it to be related with less support toward government role in the economy and more support toward business, profits, and big wages. Moreover, purity/sanctity is conceptually and empirically closely related to religion (Koleva, Graham, Iyer, Ditto, \& Haidt, 2012), and religious people were also found to have more trust in fair outcomes of the free market (Guiso, Sapienza, \& Zingales, 2003; Minarik, 2014). Therefore, from this perspective, the present findings are surprising. The other possibility is that Croatian participants are significantly different from those who participated in other studies, mostly Americans. Specifically, it could be possible that being conservative and religious in Croatia today does not imply holding specific economic attitudes, as it often implies in the USA, given that here the economic issues are not so saliently associated with political ideology. For example, Rimac (1999) showed that economic attitudes of Croatians were not coherent and could not be explained by a single left-right dimension. Labus (2009) even found that non-religious participants showed more positive attitudes toward entrepreneurship and free market than religious participants. For example, 58.7 percent of highly religious participants agreed with the statement that the state should have a larger role in the economy, compared to 43.4 percent of non-religious participants. Thus, it is possible that someone who scores high on purity/sanctity and is religious, but without ideologically determined economic beliefs, can be against markets and businesses and for the state's redistributive role. Although the precise ways in which purity/sanctity concerns are operating are not clear and cannot be disentangled in this study, it is clear that economic issues are not seen as "just" economic issues. Our results suggest that they are foremost seen as moral issues. 
In interpreting the results from the present study, it is important to consider several potential limitations. First, we used a convenience sample of people who had access to social networks and were willing to participate in the study. This could be problematic as these people could be self-selected in a way that the final sample misrepresented certain characteristics that could affect the results but were not measured or controlled for in the study. For example, the sample could be unbalanced regarding the socio-political ideology of participants which could be problematic as ideology can be significantly related to economic attitudes. Although we tried to mitigate this problem by carefully selecting those Facebook groups in which the questionnaires were posted in order to cover a broad spectrum of ideological positions, the distribution of social ideology in our sample was significantly right skewed. This means that most of the participants identified themselves as being leftist/liberals on social issues. On the other hand, the distribution of economic ideology was not skewed. Although we are aware of the drawbacks of our sample, we still hope we managed to collect a more representative sample than the university students sample, which would be, by far, the most common alternative. A further drawback, not only of the present, but of most similar studies, is that the questionnaire of the economic attitudes was constructed ad hoc, for the purposes of this study. This not only makes mutual comparisons of such studies difficult given that most of the studies use different instruments, but also fails to cover many aspects and dimensions of potentially important and meaningful economic attitudes. Our current measure includes two such dimensions, as the factor analysis suggested, while most of the others measure only one (e.g., Economic Attitudes Sophistication (EAS), Soper \& Walstad, 1983; The Market Attitudes Inventory, Lephardt \& Breeden, 2005). Thus, in order to cover all aspects of economic attitudes more thoroughly and to facilitate the mutual comparisons of individual studies of economic attitudes, developing a detailed and broad instrument that would cover much of the relevant economic themes on which people hold attitudes would definitely be a project worth pursuing in the future. Furthermore, the relatively low percentage of variance in the economic attitudes explained by predictors in this study means 
that much is still unexplained about the determinants of economic attitudes. This further opens the space for investigating other psychological concepts that could help explain the development and the structure of individuals' attitudes toward economy. For example, one of the main candidates for future research include cognitive abilities that have already been shown to be related to economic attitudes (Caplan \& Miller, 2010) and personality traits as they have previously proved to be predictive of political beliefs and attitudes (Carney, Jost, Gosling, \& Potter, 2008; McCrae, 1996; Verhulst, Eaves, \& Hatemi, 2012).

\section{Conclusion}

The present study replicated some of the previous findings indicating the importance of socio-demographic factors for the economic attitudes on the Croatian sample, but also extended them by relating them to the findings in the field of psychology. Specifically, we demonstrated that economic attitudes were predicted by moral concerns of harm/care and purity/sanctity. Thus, we have shown that economic concerns are not only economic in nature, but that at least for laypeople they also reflect moral concerns. More importantly, we have indicated the relevance of a person's psychological characteristics for his/her economic beliefs and showed that the large part of the variance of the economic attitudes still lays untapped, leaving ample opportunities for future research in this area. We believe that, by integrating the knowledge from the fields of economics and psychology, we will be a step closer to answering the questions about the origins and the true structure of laypeople's attitudes about economy and the way it should function. 


\section{Appendix}

Table A: Items Included in the First Draft of the Questionnaire, the Subscales they Constitute, and the Study they Originate From

\begin{tabular}{|c|c|c|}
\hline Item & Subscale & Origin \\
\hline $\begin{array}{l}\text { 1. Tariffs and import quotas usually reduce general } \\
\text { economic welfare. }\end{array}$ & ROSE & \multirow{5}{*}{$\begin{array}{l}\text { Alston, Kearl, \& Vaughan, } \\
\text { (1992) }\end{array}$} \\
\hline $\begin{array}{l}\text { 2. A minimum wage increases unemployment among } \\
\text { young and unskilled workers. }\end{array}$ & & \\
\hline $\begin{array}{l}\text { 3. The distribution of income in your country should } \\
\text { be more equal. }\end{array}$ & ROSE & \\
\hline $\begin{array}{l}\text { 4. The redistribution of income within the country is a } \\
\text { legitimate role for the government. }\end{array}$ & ROSE & \\
\hline $\begin{array}{l}\text { 5. The cause in the rise of gasoline prices is the } \\
\text { monopoly power of large oil companies. }\end{array}$ & & \\
\hline $\begin{array}{l}\text { 6. Private-sector involvement in the operation of public } \\
\text { infrastructure is typically inefficient. }\end{array}$ & & \multirow[b]{2}{*}{ Urzúa (2007) } \\
\hline $\begin{array}{l}\text { 7. The economic power of labor unions should be } \\
\text { significantly curtailed. }\end{array}$ & & \\
\hline $\begin{array}{l}\text { 8. The level of the legislated minimum wage should be } \\
\text { increased. }\end{array}$ & ROSE & \multirow[b]{2}{*}{ Stastny (2010) } \\
\hline $\begin{array}{l}\text { 9. The extent of government support of agriculture } \\
\text { should be increased. }\end{array}$ & ROSE & \\
\hline 10. Free trade leads to unemployment. & PCES & \multirow[b]{2}{*}{ Klein \& Buturovic (2011) } \\
\hline $\begin{array}{l}\text { 11. By participating in the marketplace in your country, } \\
\text { immigrants reduce the economic well-being of } \\
\text { locals. }\end{array}$ & & \\
\hline $\begin{array}{l}\text { 12. One of the major reasons the economy is not doing } \\
\text { as good as it could is that the business profits are } \\
\text { too high. }\end{array}$ & PCES & \multirow{6}{*}{$\begin{array}{l}\text { Washington Post/Kaiser } \\
\text { Family Foundation/ } \\
\text { Harvard University (1996) }\end{array}$} \\
\hline $\begin{array}{l}\text { 13. One of the major reasons the economy is not doing } \\
\text { as good as it could is because the top executives are } \\
\text { paid too much. }\end{array}$ & PCES & \\
\hline $\begin{array}{l}\text { 14. Looking ahead } 20 \text { years, changes that the new } \\
\text { technology and competition from foreign countries } \\
\text { are bringing will be bad for the country. }\end{array}$ & PCES & \\
\hline $\begin{array}{l}\text { 15. Trade agreements between your and other countries } \\
\text { have helped create more jobs in your country. }\end{array}$ & & \\
\hline $\begin{array}{l}\text { 16. Improving the economy is something an effective } \\
\text { government can do a lot about. }\end{array}$ & ROSE & \\
\hline $\begin{array}{l}\text { 17. Over the next five years, the average standard of } \\
\text { living in your country will fall. }\end{array}$ & & \\
\hline $\begin{array}{l}18 \text { The state must increase its control over the financial } \\
\text { sector. }\end{array}$ & ROSE & \multirow[b]{2}{*}{ Arhivanalitika d.o.o. (2015) } \\
\hline $\begin{array}{l}\text { 19. The income differences between people cannot be } \\
\text { smaller because people differ in their abilities and } \\
\text { talents. }\end{array}$ & & \\
\hline
\end{tabular}


20. Multinational companies are taking advantage of the third world workers.

21. The crisis of the Swiss franc is entirely caused by the banks.

22. The politicians are mainly responsible for the economic crisis in our country.

23. Greed is one of the main motives of business owners.

24. In capitalism, a handful of people are profiting at the expense of the majority of workers.

25. The economy operates in a way that if someone has more, someone else necessarily must have less.

Authors

26. If one became extremely rich in the free market, it is likely that the wealth was acquired illegally.

Source: Authors' construction. 


\section{Literature}

Alston, R. M., Kearl, J. R., \& Vaughan, M. B. (1992). Is there a consensus among economists in the 1990's?. The American Economic Review, 82(2), 203-209.

Blendon, R. J., Benson, J. M., Brodie, M., Morin, R., Altman, D. E., Gitterman, D., Brossard, M., \& James, M. (1997). Bridging the gap between the public's and economists' views of the economy. Journal of Economic Perspectives, 11(3), 105-118. doi: https://doi.org/10.1257/jep.11.3.105

Block, W., \& Walker, M. (1988). Entropy in the Canadian economics profession: Sampling consensus on the major issues. Canadian Public Policy/Analyse de Politiques, 14(2), 137-150. doi: https://doi.org/10.2307/3550573

Breeden, C., \& Lephardt, N. (2002). Student attitudes towards the market system: An inquiry and analysis. The Journal of Private Enterprise, 17(2), 153-171.

Burgoon, B., \& Hiscox, M. J. (2004). The mysterious case of female protectionism: Gender bias in attitudes toward international trade. Unpublished manuscript.

Burić, I., \& Štulhofer, A. (2016). In search of the egalitarian syndrome: Cultural inertia in Croatia?. Financial Theory and Practice, 40(4), 361-382. doi: https:// doi.org/10.3326/fintp.40.4.1c

Caplan, B. (2001). What makes people think like economists? Evidence on economic cognition from the "Survey of Americans and economists on the economy". The Journal of Law and Economics, 44(2), 395-426. doi: https://doi. org/10.1086/322812

Caplan, B. (2002). Sociotropes, systematic bias, and political failure: Reflections on the "Survey of Americans and economists on the economy". Social Science Quarterly, 83(2), 416-435. doi: https://doi.org/10.1111/1540-6237.00092

Caplan, B. (2006). How do voters form positive economic beliefs? Evidence from the "Survey of Americans and economists on the economy". Public Choice, 128(3-4), 367 381. doi: https://doi.org/10.1007/s11127-006-9026-z 
Caplan, B. (2011). The myth of the rational voter: Why democracies choose bad policies. Princeton, NY: Princeton University Press.

Caplan, B., \& Miller, S. C. (2010). Intelligence makes people think like economists: Evidence from the "General social survey". Intelligence, 38(6), 636647. doi: https://doi.org/10.1016/j.intell.2010.09.005

Carney, D. R., Jost, J. T., Gosling, S. D., \& Potter, J. (2008). The secret lives of liberals and conservatives: Personality profiles, interaction styles, and the things they leave behind. Political Psychology, 29(6), 807-840. doi: https://doi. org/10.1111/j.1467 9221.2008.00668.x

Cohen, J. (1988). Statistical power analyses for the social sciences. Hillsdale, NJ: Lawrence Erlbauni Associates.

Duckitt, J., \& Sibley, C. G. (2010). Personality, ideology, prejudice, and politics: a dual-process motivational model. Journal of Personality, 78(6), 1861-1894. doi: https://doi.org/10.1111/j.1467-6494.2010.00672.x

Eagly, A. H., \& Wood, W. (1999). The origins of sex differences in human behavior: Evolved dispositions versus social roles. American Psychologist, 54(6), 408-423. doi: https://doi.org/10.1037/0003-066X.54.6.408

Federico, C. M., Weber, C. R., Ergun, D., \& Hunt, C. (2013). Mapping the connections between politics and morality: The multiple sociopolitical orientations involved in moral intuition. Political Psychology, 34(4), 589-610. doi: https://doi.org/10.1111/pops.12006

Frey, B. S., Pommerehne, W. W., \& Gygi, B. (1993). Economics indoctrination or selection? Some empirical results. The Journal of Economic Education, 24(3), 271-281. doi: https://doi.org/10.1080/00220485.1993.10844799

Fuller, D., \& Geide-Stevenson, D. (2007). Consensus on economic issues: A survey of Republicans, Democrats and economists. Eastern Economic Journal, 33(1), 81-94. doi: https://doi.org/10.1057/eej.2007.5 
Furnham, A. (1987). The determinants and structure of adolescents' beliefs about the economy. Journal of Adolescence, 10(4), 353-371. doi: https://doi.org/10.1016/ S0140-1971(87)80017-9

Graham, J., Haidt, J., \& Nosek, B. A. (2009). Liberals and conservatives rely on different sets of moral foundations. Journal of Personality and Social Psychology, 96(5), 1029-1046. doi: https://doi.org/10.1037/a0015141

Guiso, L., Sapienza, P., \& Zingales, L. (2003). People's opium? Religion and economic attitudes. Journal of Monetary Economics, 50(1), 225-282. doi: https:// doi.org/10.1016/S0304-3932(02)00202-7

Haferkamp, A., Fetchenhauer, D., Belschak, F., \& Enste, D. (2009). Efficiency versus fairness: The evaluation of labor market policies by economists and laypeople. Journal of Economic Psychology, 30(4), 527-539. doi: https://doi. org/10.1016/j.joep.2009.03.010

Haidt, J., \& Joseph, C. (2004). Intuitive ethics: How innately prepared intuitions generate culturally variable virtues. Daedalus, 133(4), 55-66. doi: https://doi. org/10.1162/0011526042365555

Haucap, J., \& Just, T. (2010). Not guilty? Another look at the nature and nurture of economics students. European Journal of Law and Economics, 29(2), 239-254. doi: https://doi.org/10.1007/s10657-009-9119-5

Hayek, F. A. (2013). The fatal conceit: The errors of socialism. Abingdon: Routledge. Jost, J. T. (2006). The end of the end of ideology. American Psychologist, 61(7), 651-670. doi: https://doi.org/10.1037/0003-066X.61.7.651

Jost, J. T., Federico, C. M., \& Napier, J. L. (2009). Political ideology: Its structure, functions, and elective affinities. Annual Review of Psychology, 60, 307-337. doi: https://doi.org/10.1146/annurev.psych.60.110707.163600

Jost, J. T., Glaser, J., Kruglanski, A. W., \& Sulloway, F. J. (2003). Political conservatism as motivated social cognition. Psychological Bulletin, 129(3), 339375. doi: https://doi.org/10.1037/0033-2909.129.3.339 
Kahneman, D., Knetsch, J. L., \& Thaler, R. (1986). Fairness as a constraint on profit seeking: Entitlements in the market. The American Economic Review, 76(4), 728-741.

Kahneman, D., \& Tversky, A. (1982). On the study of statistical intuitions. Cognition, 11(2), 123-141. doi: https://doi.org/10.1016/00100277(82)90022-1

Kearl, J. R., Pope, C. L., Whiting, G. C., \& Wimmer, L. T. (1979). A confusion of economists?. The American Economic Review, 69(2), 28-37.

Kirchgässner, G. (2005). (Why) are economists different?. European Journal of Political Economy, 21(3), 543-562. doi: https://doi.org/10.1016/j. ejpoleco.2005.05.003

Koleva, S. P., Graham, J., Iyer, R., Ditto, P. H., \& Haidt, J. (2012). Tracing the threads: How five moral concerns (especially purity) help explain culture war attitudes. Journal of Research in Personality, 46(2), 184-194. doi: https://doi. org/10.1016/j.jrp.2012.01.006

Kugler, M., Jost, J. T., \& Noorbaloochi, S. (2014). Another look at moral foundations theory: Do authoritarianism and social dominance orientation explain liberal-conservative differences in "moral" intuitions?. Social Justice Research, 27(4), 413-431. doi: https://doi.org/10.1007/s11211-014-0223-5

Labus, M. (2009). Vrijednosne orijentacije i religioznost. Sociologija i prostor, 43(2), 383-408.

Leet, D. R., \& Lang, N. A. (2006, January). Is there a consensus among international economic educators? Paper presented at the $13^{\text {th }}$ Annual Meeting of the American Society of Business and Behavioral Sciences, Las Vegas, NV. Retrieved from: https://www.researchgate.net/profile/Don_Leet/publication/228430503_

Is_There_Consensus_Among_International_Economic_Educators/ links/02e7e51f5564d4806f000000.pdf 
Lephardt, N., \& Breeden, C. (2005). The market attitudes inventory: The development and testing of reliability and validity. Journal of Economics and Economic Education Research, 6(3), 63-72.

McCloskey, D. N. (2010). Bourgeois dignity: Why economics can't explain the modern world. Chicago, IL: University of Chicago Press. doi: https://doi. org/10.7208/chicago/9780226556666.001.0001

McCrae, R. R. (1996). Social consequences of experiential openness. Psychological Bulletin, 120(3), 323-337. doi: https://doi.org/10.1037/0033-2909.120.3.323

Minarik, P. (2014). Religion and economic attitudes in post-communist transition. Post-Communist Economies, 26(1), 67-88. doi: https://doi.org/10.108 0/14631377.2014.874656

O'Brien, M. U., \& Ingels, S. J. (1987). The economics values inventory. The Journal of Economic Education, 18(1), 7-17. doi: https://doi.org/10.1080/00220 485.1987.10845183

O'Connor, B. P. (2000). SPSS and SAS programs for determining the number of components using parallel analysis and Velicer's MAP test. Behavior Research Methods, Instruments, \& Computers, 32(3), 396-402. doi: https://doi. org/10.3758/BF03200807

Pratto, F., Sidanius, J., Stallworth, L. M., \& Malle, B. F. (1994). Social dominance orientation: A personality variable predicting social and political attitudes. Journal of Personality and Social Psychology, 67(4), 741-763. doi: https:// doi.org/10.1037/0022-3514.67.4.741

Pratto, F., Stallworth, L. M., \& Sidanius, J. (1997). The gender gap: Differences in political attitudes and social dominance orientation. British Journal of Social Psychology, 36(1), 49-68. doi: https://doi.org/10.1111/j.2044-8309.1997. tb01118.x

Rimac, I. (1999). Strukturiranost ideoloških opredjeljenja građana. Bogoslovska smotra, 68(4), 655-662. 
Schumpeter, J. A. (1942). Socialism, capitalism and democracy. New York, NY: Harper and Brothers.

Sekulić, D., \& Šporer, Z. (2002). Political transformation and elite formation in Croatia. European Sociological Review, 18(1), 85-100. doi: https:/doi. org/10.1093/esr/18.1.85

Sidanius, J., \& Ekehammar, B. (1980). Sex-related differences in socio-political ideology. Scandinavian Journal of Psychology, 21(1), 17-26. doi: https://doi. org/10.1111/j.1467-9450.1980.tb00336.x

Somin, I. (2016). Democracy and political ignorance: Why smaller government is smarter. Palo Alto: Stanford University Press.

Soper, J. C., \& Walstad, W. B. (1983). On measuring economic attitudes. The Journal of Economic Education, 14(4), 4-17. doi: https://doi.org/10.1080/002204 85.1983 .10845031

Tabachnick, B. G., \& Fidell, L.S. (2013). Using multivariate statistics ( $6^{\text {th }}$ ed.). Cranbury, NJ: Pearson Education Inc.

Vehovec, M. (2012). Financijska i mirovinska pismenost: međunarodna iskustva i prijedlozi za Hrvatsku. Privredna kretanja i ekonomska politika, 21(129), 65-85.

Vehovec, M., Rajh, E., \& Škreblin Kirbiš, I. (2015). Financijska pismenost građana u Hrvatskoj. Privredna kretanja i ekonomska politika, 24 (1 [136]), 53-76.

Verhulst, B., Eaves, L. J., \& Hatemi, P. K. (2012). Correlation not causation: The relationship between personality traits and political ideologies. American Journal of Political Science, 56(1), 34-51. doi: https://doi.org/10.1111/j.15405907.2011.00568.x

Vojnić, D. (1995). European integrational processes and the countries in transition with special references to Croatia and former Yugoslavia. Croatian Economic Survey, (2), 203-239.

Županov, J. (2011). Hrvatsko društvo danas - kontinuitet i promjena. Politička misao: časopis za politologiju, 48(3), 145-163. 